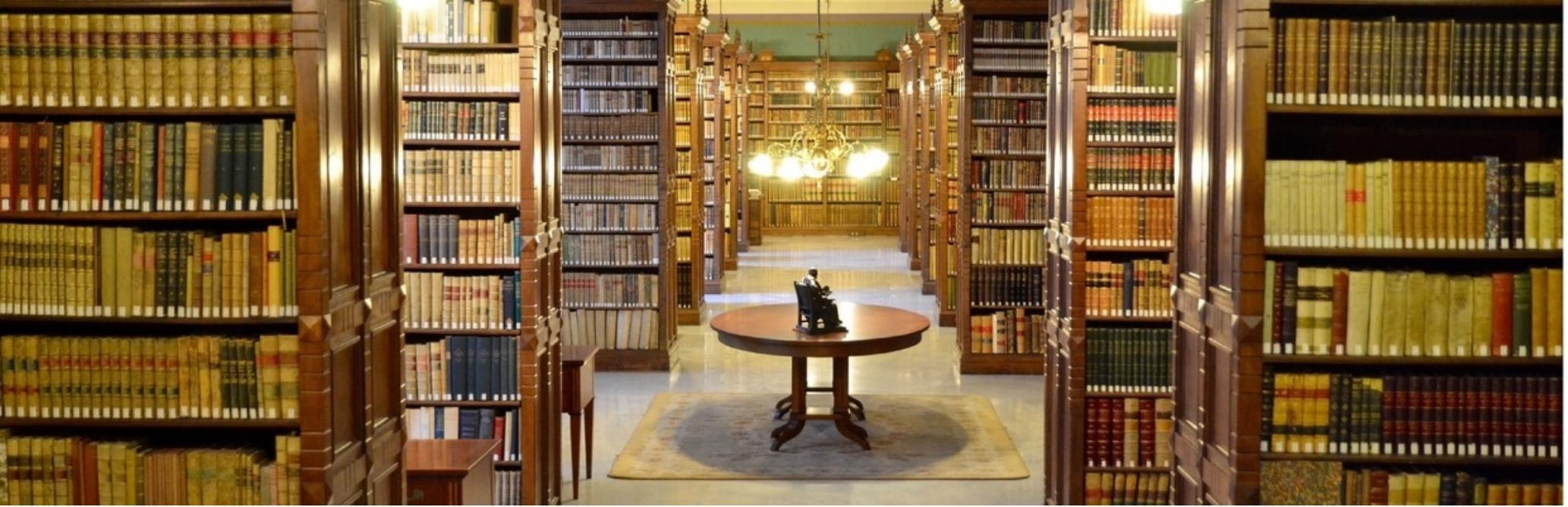

\title{
Editorial Volume 8, Issue 1
}

$\begin{aligned} \text { Authors: } & \text { Silke Masullo } \\ \text { Submitted: } & 4 \text {. March } 2021 \\ \text { Published: } & 5 . \text { March } 2021 \\ \text { Volume: } & 8 \\ \text { Issue: } & 1 \\ \text { Affiliation: } & \text { Josha Journal, Freiburg, Germany } \\ \text { Languages: } & \text { English } \\ \text { Keywords: } & \text { Editorial, JOSHA Journal, } 2021 \text { Volume 8, Issue 1 } \\ \text { Categories: } & \text { News and Views } \\ \text { DOI: } & 10.17160 / \text { josha.8.1.740 }\end{aligned}$

Abstract:

Dear JOSHA readers, In this bi-monthly issue we present you with a diverse selection of articles. We would also like to remind you that you can support us with a small donation. http://josha-journal.org/en/donate Visit our social media \#joshajournal and get to know us from the Instagram gallery and the Facebook wall. Remember that you can comment on the articles and also provide your star ranking.

\section{JOSHA Jouna ofsemeree Humanities and Arts}




\section{Editorial}

Volume 8, Issue 1

Artificial Intelligence and much more!

Artificial intelligence and data are becoming increasingly important, not only in electronic data processing, but also in medicine in particular. As an oncologist, JoSHA founder Professor Mertelsmann explores the extent to which mathematics and artificial intelligence can help improve cancer therapies. Similarly, Jona Boeddinghaus addresses ethical issues that may arise with the new methods in his paper. The contribution by Alahí Bianchini and Ignacio Mastroleo "Why the biomedical sciences need philosophy" also goes in this direction. Julieta Alcain refers to the subjectivity that even data can have. In addition to this focus, the journal offers many other exciting insights into the work of various scientists and artists.

Now we hope you enjoy reading the journal.

Dr. Stephan Seiler

Vice President

International Academy of Sciences, Humanities and Arts

Volume 8, Issue 1

Anna Munz: nonsolo Verlag: Mut zu mehr Diversität im deutschen Verlagswesen - Courage for more Diversity in the German publishing Industry

Alahí Bianchini, Ignacio Mastroleo: Why the biomedical Sciences need Philosophy: theoretical and practical Reasons illustrated with examples from the BioThera Institute of Philosophy

Johanna Patton: The Together Project: Thabarwa Meditation Center

Mei Lin Lyu: What is the Current Formal Legal Environment for Foreign Companies in China in the Light of the Phase 1 Trade Agreement?

Roland Mertelsmann: Artificial Intelligence and mathematical Models in Research and applied Oncology and Hematology

Julieta Alcain: De ratones y humanos - Of Mice and Humans

Franziska Buttgereit: Vitamin D Supplementation

Jona Boeddinghaus: Künstliche Intelligenz in der Krebsforschung und Biomedizin - Artificial Intelligence in Cancer Research and Biomedicine 